\title{
Dil, Nihilizm ve Televizyon
}

\author{
Yusuf Devran, Marmara Üniversitesi, Radyo Televizyon ve Sinema Bölümü, Prof. Dr., \\ ydevran@gmail.com, ORCID: 0000-0001-6430-1943
}

Ömer Faruk Özcan, Marmara Üniversitesi, Radyo Televizyon ve Sinema Bölümü, Arş. Gör., omer.ozcan@marmara.edu.tr, ORCID: 0000-0001-9586-3068

Anlamın ne oldŭ̆u farklı disiplinlerde çalışan araştırmacıların cevabını aradığı en önemli sorulardan biri olmuştur. Anlamın ne olduğu ve nasıl inşa edilebileceğ $i$ sorusunu soran Ferdinand de Saussure, Roland Barthes, Julia Kristeva, Jacques Derrida ve Friederich Nietzsche gibi Batıl kimi dilbilimciler ve felsefeciler göstergeden başlayarak varlık, metin ve okuyucuya kadar uzanan konularda önemli tartışmalar yapmışlardır. Neticede bu uzun serüven nihilizme kadar uzanmıştır.

İşe bir makalenin sınırlı kapsamında, bu serüven bazı boyutlarılla ortaya konulmakta; dili oluşturan göstergelerin nasıl çağ rışım gücünü yitirdiğgi, metnin öz bir metin olmaktan çıktığı, yazarın devre dışı kaldığı gibi hususlar üzerinde durulmaktadır. Göstergenin kendinden başka bir şeye işaret edememesi varlik anlamında da önemli sorunlara yol açmıştır. Çünkü kendisinden başka bir şeyi gösteremeyen göstergelerle inşa edilen ve başka metinlerle metinlerarası ilişkiye sahip olan bir metin ne müellifine, ne de yaratıcı gücüne göndermede bulunabilir.

Derrida da her bir gösterileninin aynı zamanda başka bir şeyin göstergesi olabileceğine, kökenin yokluğundan dolayı her şeyin söyleme dönüşebileceğine ve anlam alanını sonsuz genişleyebileceğine vurgu yaparak, kâinatta ilanihaye göstergeler arası bir dönüşün ve devinimin süregittiğine, dilin doğası üzerinden varlığın kendikendiliğine ve sonsuzluğuna işaret etmiştir. Bu ebedi yeniden doğuş ya da ayni olanm yeniden doğması, "kendikendinelik", varoluşun gayesini, 'yaratıcı' ile şeyler arasındaki ilişkiyi, boşa çıkarmakta ve hiçlik düşüncesini daha da pekiştirmektedir.

Üzerinde durulması gereken diğgr bir husus ise kendine özgü bir dili olan ve bu dilsel mantık üzerinden işleyen televizyonun nihilizm ile olan ilişkisidir. Bu anlamda cevabinın aranması gereken en önemli soru televizyon ve nihilizme nasıl yol açtı̆̆ $\imath d \imath$.

Anahtar : Dil, Anlam, Nihilizm, Televizyon

Kelimeler 


\section{Language, Nihilism and Television}

ABSTRACT

Keywords

\section{GíRiş}

Bu makalede, yazının başlı̆̆ından da anlaşılabileceği gibi, eşyaya ve göstergeye dair farklı bakış açıları ile hiçliğe (nihilizme) kayışın dildeki tezahürü değişik perspektiflerden ele alınmaktadır. Başka bir ifade ile içi boşaltıldığından hiçbir şey çağrıştıramayan göstergelerin işlevsizlikleri üzerinde durulmaktadır.

Bireyler içinde yaşadığı dünyayı dil aracılığıyla anlamlandırırlar. Dil ve onu oluşturan semboller, işaretler/göstergeler bir şeyin karşıllğı olarak, eşyayı çağrıştırıp anlamın inşasına 
katkı sunmaktadır. Bu nedenle yazının icadını insanlık tarihinin en önemli dönüm noktalarından biri olarak kabul etmek çok da abartı değildir. Bu muhteşem icatla birlikte kâinattaki varlıkların, eşyaların ve seslerin sembolik dilsel karşılıkları oluşturulmuş, böylece insanoğlunun iletişiminde mesajın daha kolay biçimde kodlanarak hedefe iletilebilmesinin yolu açılmıştır. Yazının mevcut olmadığı bir medeniyet tahayyülünde insanlığın bilginin üretimi, kaydedilmesi ve saklanması yeteneklerinin oldukça sınırlı kalacağı aşikârdır. Neticede belli bir sese karşılık gelen harflerin icadı, harflerin bir araya getirilerek kelimelerin üretilmesi, gramer kuralları çerçevesinde kelimelerin birbiri ardına sıralanarak cümlelerin kurulabilmesi iletişimi daha da kolaylaştırmış, aynı toplum içerisinde yaşayan bütün bireylerin ortaklaşa kullanabileceği bir dilsel sisteme kavuşmuştur.

Dil anlam inşa etme aracı ise o halde anlamın ne olduğunun da açıklığa kavuşturulması gerekir. Ferdinand de Saussure gibi yapısalcılar anlamın bir inşa olduğunu vurgulayarak, bunun nasıl gerçekleştirilebileceğinin temel ilkelerini belirlemeye çalışmışlardır. Sonuçta metnin, (değişik formda olabilir) kendisini oluşturan parçacıkların seçimi ve bir araya getirilmesiyle vücut bulacağını ileri sürmüşlerdir. Bu yaklaşım, metindeki parçacıkların belli bir "şeyi" çağrıştırdığını veya temsil ettiğini kabul etmiş ve yapının belli bir mantık ve ilkeler doğrultusunda kurulduğunu vurgulamıştır. Metni inşa edenin konumu ve katkısı burada önemli olarak nitelendirilmiş ve eserin bir anlamda sahibinin ve mimarının kapasitesine, kudretine ve vasıflarına işaret ettiği savunulmuştur.

Oysa Derrida ve Riffaterre gibi postyapısalcılar metnin tek bir anlamının olduğu görüşünü reddederler. Çünkü her bir okuyucu herhangi bir metinle ilgili yeni bir anlam oluşturabilir.

$\mathrm{Bu}$ çalışmada aslında kendinden başka şeylere işaret eden göstergelerin anlam ifade etmesinin yaşamın ve varlığın manası bakımından ne kadar hayati olduğu, diğer taraftan referansını kaybeden göstergelerin insanlık açısından ne gibi boşluklar ortaya çıkarabileceği ve hiçliğe yol açabileceği tartışılmaktadır. Özellikle izleyiciye sürekli olarak göstergeler pompalayan televizyonun bu süreçteki katkısının ne olduğu sorusu daha da önemli hale gelmektedir. Çünkü televizyon özellikle görsel göstergelerle işleyen bir aygittır. Bu nedenle üzerinde özellikle durulması gereken hususlardan biri televizyonların tercih ettiği göstergelerin ve bu göstergelerle iletilmeye çalışılan mesajların neler olduğu ve izleyicilerin nihilizme meyletmelerine nasıl yol açabileceğidir. Bu bağlamda makale kapsamında özellikle şu sorulara cevap aranacaktır:

1. Sembolik dil doğadaki varlıkları, eşyayı nasıl ifade etmekte ve çağrıştırmaktadır?

2. Bu çağrışımın mantığ nasıl işlemektedir?

3. Dilbilimcilerin ve felsefecilerin göstergeye ve anlama ilişkin yaklaşımları nedir?

4. Göstergelerin içi nasıl boşaldı veya göstergeler çağrışım gücünü nasıl yitirdi? 
5. Televizyon metinlerinin dili nasıl inşa edilmektedir?

6. Televizyon ve nihilizm arasındaki ilişki nasıl kurulmaktadır ya da televizyon nihilizme nasıl yol açmaktadır?

$\mathrm{Bu}$ ve benzeri soruların cevapları makalenin sınırlı kapsamı çerçevesinde aranmaya çalışılacaktır.

\section{Dilin Varlıkla İlişkisi}

Jacques Ellul Sözün Düşüşü adlı kitabında "İnsanlığ1 kurtarma isteği duyan herkes günümüzde, öncelikle dili kurtarmalıdır" diyordu (Ellul, 1998, s. 9). Çünkü Martin Heidegger'in de ifadesiyle dil varlığın evidir. Bireyler toplum içerisinde kullandı̆̆ şekillenir (Heidegger, 1993). Başka bir ifadeyle dil bireylerin kimliğinin ve varlığının şekillenmesinde önemli bir işlev gördüğü gibi, aynı zaman da hakikati açıklayan en önemli araçtır. Aslında Ellul'un bu uyarısı, her şeyin anlamını yitirdiği, göstergelerin kendinden başka bir şey ifade etmediği, yazarın öldüğü, orijinalitenin yok olduğu, saf bir metin iddiasında bulunulamayacağı, anlamın değil artık orada burada uçuşan anlamların olduğu, dilin işlevsizleştiği ve dil olmaktan başka şeye dönüştüğü gibi görüşlerin ortaya atıldığ ve savunulduğu bir zaman diliminde daha da önem arz etmektedir.

Antik çağın filozoflarından Diogenes de güpegündüz eline fener alıp Atina pazarına dalarak “İnsan arıyorum!" diye bağırması gibi Alman Filozof Friederich Nietzsche de iki bin yıl sonra, benzer şekilde, asırlardır kendisine iman edilen Tanrı'nın, müntesipleri tarafından öldürüldüğünü ileri sürerek Tanrı'yı aramaya koyulmuştu. Çünkü artık Tanrı metafizik, iyi ve kötü insan ufkundan tamamen kaybolmuş ve ortak şuur nihilist bir krize sürüklenmiştir (Özkan, 2004, s. 49-53).

Özkan'a göre, nihilizmin neşet ettiği Nichts/hiç merkezinde hiçin oturduğu bir durumu izah eder ki burada bir şeyin eksikliği ve yokluğu söz konusudur. Kesin bir şeye istinat etmeyen, müphem ve kaypak bir kavram olan Nichts felsefe disiplininde gerçekten hiçbir şeyin var olmadığını ifade eder. Etik perspektifinden bakıldığında ise Nichts iyi ve kötü arasındaki farkı reddeder. Augustinus hiçbir şeye inanmayanlara nihilist diyordu. Başka bir nokta-i nazardan bakıldığında Nichts, varoluşun kötü olduğunu, gerçek olmadığını ve dolayısıyla yok oluşla aşılması lazım geldiğini savunur (Özkan, 2004, s. 55-56).

Batılı insan, Tanrı'sını bir anlamda göstergeleri işlevsizleştirip çağrışım gücünü yok ederek ve eşya ile yaratıcısı arasındaki bağı kopartarak imha etmiştir. Fransız dilbilimci Roland Barthes (2016) “Göstergeler Imparatorluğu” adlı eserinde, Japon kültüründen hareketle, gösterilenden daha büyük önem kazanan ve kendinden başka bir şey ifade etmeyerek içi boşalan göstergelere vurgu yapmaktadır. Barthes'in Japonya'sında asıl haz, gösterilende değil gösterendedir, içerik dönüşsüz olarak kovulmuştur, Japon gösteren dizgesi bir göstergeden 
çok sunmadır. Japonya'da saygı göstergeleri anlam üretmez, nazikçe eğilme devinişi başka bir şeye göndermez (Akay, 2017, s. 233). Simülasyon uygulamaları dikkate alındığında, günümüz açısından durumun daha da vahim olduğu söylenebilir. Çünkü hiçbir simülasyon objesi/göstergesi kendisinden başka bir şeye işaret etmemektedir (Genosko. 2002, s. 28-68).

Konunun daha kolay anlaşılabilmesi için göstergenin ne olduğunun, neyi ifade ettiğinin izah edilmesi gerekmektedir. Göstergebilimin kurucusu kabul edilen Ferdinand D. Saussure kendisinden başka bir şeye işaret eden her bir dilsel işaretin yani göstergenin bir gösteren ve gösterilenden mürekkep olduğunu ifade etmiştir. Yani fiziksel bir görünüşün ve karşllık geldiği anlamın ne olduğu üzerinde durmuştur. Roland Barthes ise göstergelerin düz yani birinci düzey anlamının yanı sıra yan anlamlarının da olabileceğini vurgulayarak işlevini ve kapsamını daha da genişletmiştir (Chandler, 2007, s. 137). Mesela "çiçek" görseli Saussure için bir bitkiyi çağrıştırırken, Barthes, yan anlam olarak, romantizmi de ifade edebileceğini dile getirmiştir. Hatta bazı bitkilerin ideolojik bir anlam kazanarak mitsel bir fonksiyon icra etmesi de mümkündür. Sözgelimi, lalenin siyasi bir dönemi çağrıştırması gibi. Bu arada göstergeye farklı bir bakış açısı da Amerikalı Charles Sanders Pierce'ten gelmiştir. Ona göre temsil edilen eşyanın formu yani fiziksel biçimi (representamen), göstergenin anlamı (interpretant) ve göstergenin kastettiği (referent) objeden söz edilebilir (Chandler, 2007, s. 29).

Okuyucunun zihninde göstergenin bir anlam oluşturabilmesi için göstergenin kastettiği objenin zihinde temsili bir karşılığının bulunması elzemdir. Başka bir anlatımla dış dünya göstergeleştiği ölçüde tanınabilir. Tabii ki, göstergelerin bir anlam ifade etmesi ve insan zihninde çağrışımlarda bulunması kaydı şartıyla. Aksi takdirde hiçlik kaçınılmaz olacaktır. Çünkü gösterge ile gösterdiği veya çağrıştırdığı nesne arasındaki ilişki koparıldığında anlam yerini anlamsızlığa bırakmakta, dil ile tasavvur edilen evrenin içi boşalmakta, keyfi ve nedensiz bir hale gelmektedir. Sonuçta anlam değil sadece gösterge kalacaktır.

Barthes'in "Göstergeler Imparatorlŭ̆u"nda ifade ettiği gibi, kendinden başka hiçbir şeyi göstermeyip boşluğa işaret eden göstergelerden oluşan metin Budist anlayışın ve bu düşünce sisteminin açıldığ sıyrılmış göstergeler düşü, Barthes'i Zen'ci bir anlayışa yaklaştırmaktadır. Zen Budizm'inin ana gayesi "satori" anlayışıdır. Satori Japonca'da aydınlanma anlamına gelmektedir. Zen geleneğinin kalbi olarak adlandırılan Zazen, oturarak yapılan bir meditasyon pratiği olup Budistlerin en çok uyguladıkları pratiktir ve de zihnin boşaltılmasını amaçlamaktadır. Çünkü zihin boşaltıldığı zaman orada hiçbir atıf, hiçbir kök ve öz kalmayacaktır. Zazen, herhangi bir amaç gözetilmeksizin, yalnızca oturmayı; beden ve zihni sakinleştirerek varoluşun mahiyetini sezgiyle deneyimlemeyi, böylece Satori'ye (aydınlanmaya) ulaşmayı amaçlamaktadır. Zen'in ibadet etmek için bir Tanrı'sı yoktur, temaşa edilecek ayin törenleri yoktur (Akay, 2017, s. 228229). 
Nietsche'nin görüntüye dair bakışını ise Özkan (2004, s. 202) şu şekilde dile getirmektedir: Nietsche ne hakikati görüntü olarak görür ne de görüntüyü hakikate dönüştürür. Tam aksine filozof şimdiye kadar hakikatle görüntü arasındaki görünmeyen o kategorik zinciri koparır. Artık görüntü varlıktan bağımsız realite olarak tecelli edebilir. Bundan böyle suret, ne varlığın bir görüntüsü ne de bir muska gibi mahiyetinin ne olduğunu hiç bilmediğimiz, bilemeyeceğimiz özün, cevherin kendini bir görüntü olarak sunmasıdır. Gariptir ama o, apaçık bir surettir ve öze has hiçbir özelliğe muhtaç değildir.

Gösterge bir gösterilene göndermede bulunamıyorsa, yani gösterge değilse eşyanın hikmeti vücudu üzerinde durmanın da bir anlamı olamaz. Sonuç, işte bu yüzden, nihilizme yani hiçliğe varmaktadır. Nietzsche Budha'nın, reenkarnasyon yani "ebedi yeniden doğuş" nazariyesini Özkan'ın ifadesiyle "Budizm'in Avrupai bir formu” olarak telakki etmiştir (Özkan, 2004, s. 115). Bu ebedi yeniden doğuş ya da ayni olanın yeniden doğması, "kendikendinelik" varoluşun gayesini, yaratıcı ile varlıklar/canlılar arasındaki ilişkiyi boşa çıkarmakta ve hiçlik düşüncesini daha da pekiştirmektedir. Oysaki hem Budha hem de Nietzsche yaşamları boyunca bu kısır döngüyü aşmak için adeta çırpınmışlardır.

\section{Anlamın Yok Oluşu ve Yazarın Dışlanışı}

Felsefeciler ve dilbilimciler "anlam nedir ve nasıl inşa edilebilir" sorusunu sorarak önemli bir çaba içerisine girmişlerdir. Göstergebilimcilere göre anlam belli bir paradigmadan (paradigm) seçilen göstergelerin belli bir sentaksa göre sıralanmasıyla oluşmaktadır. Belli bir fiziksel biçimi olan gösterge ile gösterilen arasındaki ilişki keyfi olup herhangi bir nedene dayanmamaktadır. Bir göstergenin anlamı, onun ne olduğundan değil ne olmadığından kaynaklanmaktadır (Chandler, 2007, s. 90). Sözgelimi “biz”, “öteki” olmadığımızdan dolayı biziz; bizi anlamak için ötekini bilmek gerekir. Dolayısıyla öteki olmasaydı biz de olmayacaktık, bizi anlamlı kılan da ötekidir. Öteki varlığımızın vücut buluşu ve devamı açısından yaşamsal düzeyde önem arz etmektedir

Anlamı yok etmek ve arkasındaki yazarı gizleyebilmek için metnin yok edilmesi, özün, orijinalliğin kaybedilmesi, ya da metnin içindeki unsurların zihinsel karşılıklarının, çağrışımlarının, yani referanslarının ortadan kaldırılması gerekirdi. Kristeva'nın "metinlerarasılık" kavramı tam da bu noktada imdada yetişir. Kristeva'ya göre her metin alıntılardan oluşan bir mozaiktir. Her metnin bir başka metinden oluşması onun dönüşüme ve değişime uğramasıdır (Akay, 2017, 212). Barthes de Kristeva gibi düşünerek kapalı metin olamayacağına vurgu yapmıştır (Aktulum, 2014, s. 12).

Metinlerarasılık kavramı her ne kadar Kristeva'ya atfedilse de, aslında kavram özünü Rus eleştirmen Mihail Bakhtin'den almıştır. Bakhtin'in söyleşimcilik/dialogisme adını verdiği kurama göre bir sözce başka sözcelerle ilişki halinde olmadan, birbirlerini etkilemeden var olamaz (Aktulum, 2014, s. 22). Netice olarak öz metin diye bir şeyden söz edilemez ve 
metinlerin hiçbiri orijinal bir metin değildir. İlk saf metne ulaşmak için metinler arasında ilanihaye seyrüsefer yapılsa da atıfsız, alıntısız, ilintisiz, çizik atılmamış bir metne ulaşmak mümkün değildir. Çünkü bir metnin işaret ettiği şey başka bir metindir. Onun işaret ettiği de öteki bir metindir. O halde yazar denilen "şey" orijinaliteyi ortaya koyan değil, hatta belki yazar da değil, oradan buradan derleyip toplayan bir "işçidir" ancak. Dolayısıyla kendisi yazmamıştır ve inşa etmemiştir, adeta kolaj yapmıştır. Zaten metin okunurken yazara da gidilemez, çünkü her şeyin kendine ait olduğunu iddia eden bir yazar da ortaya çıkamaz.

Kristeva gibi metinlerarasılık kavramını kullanan Michael Riffaterre ise metinlerarasını büyük ölçüde okur-metin arasındaki ilişkiye göre tanımlamaktadır. Riffaterre böylelikle tanımlamalarını bir alımlama kuramı çerçevesine oturtarak metinlerarasının her şeyden önce bir okuma etkinliğine bağlı olduğunu ifade etmiş ve ilk kez okura önemli bir görev yüklemiştir. Yazınsal iletişim ve metinler arasındaki ilişkiler okurca algılanmadıkça gerçekleşmez (Aktulum, 2014, s. 50).

Birilerinin ortaya çıkıp metnin saf, sahih ve kendi başına dört başı mamur bir eser olduğu iddiasını çürütebilmesi için metinlerarasılığı kullanması tam da sadra şifa olmayabilir. Çünkü özün ve öznelliğin yok edilebilmesi için metin içerisindeki göstergelerin de adeta içinin boşaltılması, işlevsizleştirilmesi ve şeyleştirilmesi gerekirdi. İşte tam bu noktada Derrida'nın "differance" kavramı devreye sokulmuştur.

Nietzsche'nin vurguladığg "ebedi tekrar dönüş"ü, Jacques Derrida, dil bağlaminda kullandığ1 yeni bir kavramla dile getirmiştir. Derrida, "differance" kavramını kullanarak her bir gösterilenin aynı zamanda bir başka şeyin göstergesi olabileceğini vurgulayarak ilanihaye göstergelerarası bir dönüşün, devinimin süregittiğini vurgulamakta, dilin doğası üzerinden varlığın kendikendiliğine ve sonsuzluğuna işaret etmektedir.

Difference sözcüğünden türetilen "differance" kavramı adlandırılamaz bir kökensizliğe işaret etmektedir. Lügatte Türkçe karşıllı̆̆ farklılık olarak geçen difference sözcüğü aynı zamanda “erteleme" anlamı da taşımaktadır (Küçükalkan, 2017, s. 70-75). Bu erteleme Derrida'nın, Saussure'ün gösteren gösterilen ilişkisine ilişkin iddiasını çürütmek için yeterli olabilirdi. Artık sabit bir gösteren gösterilen ilişkisi iddia edilemezdi, zira her bir gösteren bir gösterilene işaret ederken, aynı zamanda gösterilen şey de başka bir gösterilenin göstereni olabilir ve gösteren gösterilen arasındaki zincir sonsuza kadar devam edebilirdi.

Neticede gösteren gösterilen arasında sabit bir ilişkiden söz edilemeyeceği için, metnin adeta tuğla taşları olan göstergelerin çağrışımlarından hareketle o metne ilişkin sabit bir anlam çıkarmak da mümkün değildir. Çünkü kökenin yokluğundan dolayı her şey söyleme dönüşür ve anlam alanı sonsuz genişleyebilir (Derrida, 2001, s. 354). Derrida'nın "difference" sözcüğünden "differance" kavramanı üretirken kullandığı ' $a$ ' harfiyle vurgulanmak istenen şey işte bu hareketliliktir. Böylece o, kâinatta ilanihaye göstergeler arası bir dönüşün ve 
devinimin süregittiğine vurgu yaparak, dilin doğası üzerinden varlığın kendikendiliğine ve sonsuzluğuna işaret etmiştir.

Dolayısıyla öz bir metin yoksa, mutlak bir gösterilen yoksa, sonsuz sayıda anlamlandırma zinciri üzerinde tamamlanmamış olan anlamın yeniden üretimi söz konusuysa mutlak bir yazarın varlığından da söz edilemez. O halde yazarı da "öldürmek" gerekir. İşte neticede yapılan da buydu: "Yazarı öldürmek." Derrida da bu yüzden "Metinden başka bir şey yoktur" diyordu (Derrida, 1997, s. 158).

Yazar saf dışı edildiyse sıra özü ya da öz metni inşa eden müellifin yok edilmesine gelebilirdi. Bu işi halletmek de Nietzsche'ye nasip olmuştur. Nietzsche Tanrı'nın ölümünü ilan ederken, aşkın bir göstereni, metafizik zorunluluğu yadsımaya çalışmıştır.

Netice olarak, artık göstergelerin anlam taşıyan işaretler olarak kabul edildiği bir zaman diliminden çıkılmış ve göstergelerin gerçek "gösterge" olup olmadığı tartışılmaya başlanmıştır. Çünkü kendinden başka bir şeyi gösteremeyen işarete ne derece "gösterge" denebilir ki! Dahası bu göstergelerle inşa edilecek bir metnin gerçek anlamda bir metin olup olmadığı nasıl savunulabilir?

Öte yandan kendisinden başka bir şeyi gösteremeyip adeta boşluğa ve hiçliğe işaret eden göstergelerle inşa edilen bir metin ne müellifine, ne de yaratıcı gücüne göndermede bulunabilir. İşte böyle bir metin ancak hiçliğe vurgu yapan nihilizme; boşluğa, boşalmaya, bu dünyadan başka bir dünyanın olmadığını, her şeyin bu dünyada olup biteceğine dolayısıyla bu dünyadaki sıkıntıları ve meşgaleleri zihnimizden çıkarabilirsek, kendimizi boşluğa bırakabilirsek huzur bulabileceğimizi vurgulayan dinsel inanışlara hizmet edebilir.

Eğer saf ve mutlak bir metin ve bu öz metni ortaya çıkaran bir yazar yoksa metni okurken onu düşünmeye de gerek yoktur, anlamlı da olmaz zaten. Oysa yazar merkezli edebiyat teorileri metnin anlamını göstergeler üzerinden değil, yazarı merkeze alarak okumayı yeğlemişlerdir (Kolcu, 1961). Yani yazarın düşüncesine, ideolojisine, yaşam biçimine ve yaşadığ1 şartlara bakılarak metniyle neyi ifade etmek istediği anlaşılmaya çalışılmıştır. Eğer yazar öldüyse veya öldürüldüyse böyle bir yöntem bize neyi verebilir!

Postmodernistler yazarı öldürdüklerinden, çıkış yolu bulabilmek için okuyucuya odaklanmış ve anlamı metinde veya yazarda değil, okuyucuda aramışlardır. Metinlerarasılığa göre de, bir metnin ne kadar okuyucusu varsa o kadar anlamı vardır. Metin okurların müktesebatına, belleğine ve idrak seviyesine göre genişler, zenginleşir, boyut kazanır. Yapıçözüm de her okumanın metinlerarası bir okuma olabileceğini ileri sürerek metinlerarasılıkla aynı noktada buluşmaktadır (Akay, 2017, s. 213-214). Ancak bu okumanın doğru bir okuma olup olmadığını kimse garanti edemez. Nitekim Paul De Mann her okumanın yanlış okuma olduğunu ve her 
yorumun yanlış bir yorum olacağını ileri sürmüştür (Akay, 2017, s. 13). Böylece her zaman yeni bir okumaya ihtiyaç olduğuna vurgu yapmıştır.

\section{Televizyon ve Nihilizm}

Televizyon bir kitle iletişim aracı olarak izleyiciyi bilgilendirebilir, eğitebilir, eğlendirebilir. Televizyon ayrıca kamusal alan işlevi görerek değişik tartışmalar için zemin oluşturabilir. Bu anlamda televizyonun fonksiyonu yadsınamaz. Ancak sorun bu aracın bu içerik ve formatlara kendi doğasını egemen kılarak, başka bir ifadeyle bütün formatları birer eğlencelik yapımlar haline getirerek, içerik ve anlamlarının yok olmasına yol açmasıdır. Haberlerin, siyasetin, tartışma programlarının vs. içeriklerinden daha ziyade biçimleri önemli görülmektedir. $\mathrm{Bu}$ yüzden kavga ederek konuşan tartışmacılar televizyon yöneticileri için daha makbuldür; görsellik ve eğlence içeren haberlerin haber bültenlerinde yer alması daha olasıdır; magazin boyutu olan siyasiler televizyonların adeta kadrolu müdavimleridir. Dahası siyasetçiler televizyonlarda soyut mesajlarının yayınlanmasını güvenceye alabilmek için mesajlarına görsellik katmak zorunda kalmaktadır.

Televizyonun bir araç olarak mahiyetini Neil Postman “Televizyon Öldüren Eğlence” adlı kitabında özetle şöyle açıklamaktadır: Sorun televizyonun eğlence yayınlaması değil, bütün formatları eğlenceye dönüştürmesidir. Televizyonda söylem görsel imajlarla yansıtılmaktadır. Televizyon konuşmayı bize sözle değil görsel imajlarla aktarmaktadır. İmaj yaratıcısı öne çıarken söz yazarı geri plana düşmektedir. Televizyonda politik felsefe yapılamaz. Televizyon bakılacak haberleri ekrana getirmektedir. Eğlence televizyondaki her türlü söylemin üst ideolojisidir. Güzel görüntüler haz kaynağıdır. Televizyon okuma yazma kültürünü genişletmez, pekiştirmez, tersine okuma yazma kültürüne saldırır (Postman, 1999).

Televizyon ile nihilizm arasındaki ilişkinin ortaya konulabilmesi için televizyonun bir araç olarak doğasıyla nihilizm felsefesinin örtüştüğü hususların tespit edilmesi gerekmektedir. Başka bir ifadeyle sorulması gereken soru nihilizm ile televizyon arasındaki ilişkinin kapsamının ne olduğudur. O nedenle nihilizm kavramının bu anlamda açıklanması gerekmektedir.

Nihilizm Latince nihil kelimesinden neşet etmekte ve hiçbirşey anlamına gelmektedir. Nihilizm anlamın ve amacın eksikliğini ifade eden felsefi veya yaşam anlayışı olup iyi ile kötü, güzel veya çirkin, daha iyi veya daha kötü, asil veya basit arasında bir ayırım yapmanın bir temelinin dayanağının olmadı̆̆ı anlamına gelmektedir.

Nihilizm sözcüğü acıyı, çatışmayı ve antagonizmayı kabul edememe halini anlatır. Acısız bir yaşam arayışı, dünyayı olduğu gibi kabul etmemekle aynı kapıya çıkar. Çünkü acı, çatışma ve antagonizmanın artık var olmadığı yanılsamalı bir dünya, aşkın bir cennet icadıdır (Nietzsche'den aktaran Diken, 2011, s. 13). 
Direk'e (2016) göre nihilizm kendisine dayanılacak hiçbir şeyin kalmadığı̆, her şeyin anlamını yitirdiği bir dünyaya işaret etmektedir. Başka bir ifade ile nihilizm bu dünyada uğruna mücadele edilebilecek hiçbir değerin kalmadığına, bu anlamda bir anlamsızlığa vurgu yapmaktadır. Böyle bir dünyada her şey olabilir, kabul edilebilir ve geçerli olabilir. Bu dünyada eğer anlamsızlık söz konusu ve egemense o zaman hiçbir kişiye olaya, habere bir anlam atfederek yorumlamak da anlamsızdır. Dolayısıyla bütün bu içeriklerin tek bir işlevi var ekranda zamanı doldurmak ve izleyicileri avutmak, eğlendirmek.

Nietzsche de "Tanrının öldüğünü" ileri sürerken, bunu ateist bir misyoner edasıyla yapmayıp aslında nihilist bir krizi haber veriyordu. Çünkü beşeriyetin tanrıdan, ebedi hakikatten ve mutlak varlıktan kopuşu söz konusudur. Çünkü insanlık sürekli düşüş halindedir; sağa, sola, ileriye ve her yana savrulmaktadır. Dolayısıyla nihilizm bu bağlamda ruhun girdiği krize işaret etmektedir (Özkan, 2004, s. 53).

Nihilizm insanın, bir istem konusu olan değer ve amaçlardan yoksun kalınca hiçliği istemesidir (Nietzsche, 2005, s.51). Nihilizmin üstesinden gelinebilmesi, onun aynı zamanda onaylanmasına bağlı olduğundan, nihilizmin sorun olmanın yanı sıra fırsat olarak da görülmesi gerekmektedir. Çünkü değerlerin değersizleşmesi yeni değerlerin yaratılması için gereklidir. Nietzsche, nihilizmin bir fırsat olarak görülüp onaylanmasını da aktif nihilizm olarak değerlendirmektedir (Küçükalp, 2005, s. 3).

İki tür nihilizm anlayışından söz edilebilir: Aktif nihilizm ve pasif nihilizm. Aktif nihilizm bu dünyanın olumsuzlanmasını mantıksal uç noktasına, gerçek dünyanın yok edilmesine götürerek aşkınlıkta ısrar etmektedir. Pasif nihilizm ise gerçek dünyadan hoşnuttur, fakat kötücül niteliklerini, başka bir deyişle, tutkularını ve değerlerini istemez. Bir taraftan bir dünya bulamayan değerler, diğer tarafta ise değerlerin bulunmadığı bir dünya vardır. Öte yandan aktif ve pasif nihilizmin birbirinin zıddı olmaktan ziyade tamamlayıcısı olduğunu belirtmek gerekmektedir (Diken, 2011 s. 13; 21). Pasif nihilizme göre yanlış olan değerlerdir, dünyanın kendisi değil, fakat aktif nihilizme göre sorun değerlerde değil, dünyanın kendisindedir (Diken, 2011, s. 45).

Nietzsche nihilizmin bulgularını toplumsal keder, fizyolojik bozulma, ahlaksal çöküntü, yaygın kötümserlik vb. olarak sıralamaktadır. Bu noktada sorulması gereken soru medya ile nihilizm arasında ne gibi bir ilişkinin olduğudur. Fellow ve Vincent (2010, s. 4) televizyonun nihilizmle ilişkisinin en çok kriz anlarında ortaya çıktığını vurgulayarak televizyonun olayları abartması, basit meseleleri kriz olarak sunması, gerçek krizleri ise özünden uzaklaştırarak izlencelik bir nesneye dönüştürmesini medya nihilizmi olarak tanımlamaktadır. Başka bir anlatımla medya nihilizmi gerçekliği ve toplumun kritik konulara ilişkin farkındalığını çarpıtmaktadır. Medyanın büyük bir sorunun içinden çekip öne çıkardığı, abartarak tansiyonun yükselmesine yol açan parça her şeyin önüne geçer ve bu soruna ilişkin nadiren 
bir çözüm üretilir ve genellikle bir çözümsüzlük söz konusudur. Medya nihilizm ayrıca irrasyonaliteyi beslemekte ve izleyiciye negatif duygular üzerinden kanaat oluşturmalarını sağlamaya çalışmaktadır ki bu mantığa ve gerçeğe aykırıdır.

Postman'ın (1999, s. 79) medya araçlarının enformasyonu bağlamından koparttı̆̆ı iddiası bu noktada medya nihilizminin beslendiği bir husus olarak görülmelidir. Zira bilginin toplum için arz ettiği önemden ziyade hızlı ve sansasyonel biçimde aktarılması özellikle televizyon gibi görsel göstergelerle metin inşa eden araçlar için bir seçenekten ziyade bir kriter haline gelmiştir.

$\mathrm{Bu}$ durum toplumun yaşam kalitesini olumsuz etkilemekte ve önüne geçilemeyen, çı̆̆ gibi oluşan çok zayıf kanaatlerin oluşturmasına yol açmaktadır. Televizyonlarda sürekli olarak krizlerin ve akabinde başarısızlık retoriğinin yayınlanması başarısızlık beklentisinin bir kültür haline dönüşmesine yol açabilir. Bu daha büyük bir sosyal keyifsizliğe, umutsuzluğa yol açabilir. Sözgelimi bu başarısızlık beklentisi bireyler arasında sosyal yabancılaşmaya, iletişimsizliğe, kin ve düşmanlığa yol açabilir.

\section{Sonuç}

Kimi dil bilimciler ve felsefeciler göstergelerin, eşyanın ve metnin anlamını algılayabilmek için uzun süre düşünüp tartışmışlardır. Eşyanın göstergesi için düz anlam, yan anlam, mitsel anlam gibi kavramlar geliştirmişlerdir. Ardından göstergenin gösterdiği şeyin (gösterilen) başka bir şeyin göstergesi olacağı dolayısıyla sabit mutlak bir gösterilenin olamayacağını dile getirmişlerdir. Dahası göstergenin içinin boşalması ve çağrışım gücünü yitirmesi nedeniyle kendinden başka bir şeye işaret edemeyeceğini belirtmişlerdir. Böylece dil Akay'ın da vurguladığı gibi dilsiz işaret sistemine, dilsizliğin diline dönmüştür (Akay, 2017, s. 11). Ayrıca Kristeva gibi kimi dil bilimciler hiçbir metinin başka bir metinden esinlenmeden, alıntı yapılmadan inşa edilemeyeceğine, mutlaka metinlerarası bağlantılarının olduğuna işaret etmişlerdir. Başka bir anlatımla öz bir metnin olamayacağını ileri sürmüşlerdir. Öz bir metin yoksa özgün bir yazardan da söz edilemez.

Göstergenin içi boşalmışsa ondan mürekkep metin ne kadar anlam ifade edebilir ki! Dahası, postmodernistler ise yazarı da öldürerek metnin yazar üzerinden okunup anlaşılmasının da yolunu kapatmışlar ve işi tamamen okura bırakmışlardır. Dolayısıyla metnin anlamı değil okurların ondan ne anladığı üzerinde durulmuş, artık anlamın değil, anlamların olabileceği ileri sürülmüştür. Netice olarak gösterge işlevini yitirmiş, metin özgün olmaktan çıkmış ve yazar da yok edilmiştir. Bu durum, nihilizmi "hiçliğii" benimseyen düşünceyi pekiştirmiş ve "hiçliğin" bir kurtuluş vesilesi olabileceği anlayışının işini kolaylaştırmıştır.

"Nothing" sözcügüünden türeyen nihilizm her şeyin anlamını yitirdiği bir dünyaya işaret ederken bu dünyada uğruna mücadele edilebilecek hiçbir değerin kalmadığına, yani anlamsızlığa vurgu yapmaktadır. Böyle bir dünyada ise her şey olabilir, kabul edilebilir ve 
geçerli olabilir. Televizyonun bir kitle iletişim aracı olarak bu dünyanın oluşmasına yönelik katkısı olduğu gibi, bu dünyaya ilişkin kanaatin daha yaygın bir hale gelmesine yol açabileceğini söylemek mümkündür. Çünkü bu aracın doğası böyle bir dünya içerisinde daha rahat hareket edebilmeyi gerekli kılabilir.

Mezkûr yönüyle pasif nihilizmi körükleyen televizyonun toplumsal dinamikleri olumsuz yönde etkilemesi kaçınılmazdır. Zira anıldığı gibi kriz anlarında doruğa çıkan bu hal televizyonun olağan yapısı haline gelmiştir. Ne yazık ki rekabet hırsı nedeniyle kamu yayıncılı̆̆ bulunmamaktadır. Netice olarak birey, toplum ve medya arasındaki ilişki biçiminin ve düzeyinin yeniden gözden geçirilmesi, bireylerin kendilerine ait kararları kolaylıkla alabilmelerini sağlayabilecek şeffaf iletişim politikalarının geliştirilmesi gerekmektedir. Ayrıca televizyon yayıncılık felsefesinin yeni bir değerlendirmeye tabi tutulması, mevcut yayıncılık paradigmasının sorgulanması gerekmektedir ki bu yeni akademik çalışmaların yapılmasını zorunlu kılmaktadır.

\section{Kaynakça}

Akay, H. (2017). Anlamın Çağrısı, Kuramlar ve Okuma Biçimleri üzerine. İstanbul: Şule.

Aktulum, K. (2011). Metinlerarasillk Göstergelerarasılık. İstanbul: Kanguru.

Aktulum, K. (2014). Metinlerarası İlişkiler. İstanbul: Metis.

Barthes, R. (2014). Göstergebilimsel Serüven. İstanbul: Yapı Kredi.

Chandler, D. (2007). Semiotic the Basics. London: Routledge.

Derrida, J. (1997). Gramatoloji. London: The Johns Hopkins University Press.

Derrida, J. (2001). Writing and Differance. (A. Bass, Çev.) London: Routledge Classics.

Diken, B. (2011). “Nihilizm”, A. Onacak (çev.), İstanbul: Ayrıntı Yayınları

Direk, Z. ( Zeynep Direk). (4 Temmuz 2017). Jacques Derrida Zeynep Direk İle Felsefe Vakti Türkçe (https://www.youtube.com/watch?v=w0nW-Dsnu-U) adresinden erişilmiştir.

Ellul, J. (1998). Sözün Düşüşü. İstanbul: Paradigma.

Heidegger, M. (1993). Basic Writing. San Francisco: Harper San Francisco.

Hogan, J. Michael. (1989). Media nihilism and the presidential debates. Argumentation and Advocacy, 25 (4: Spring, 1989), 220-25.

İnceoğlu, Y. G. ve Çomak, N. A. (2016). Metin Çözümlemeleri. İstanbul: Ayrıntı.

Kolcu, A. İ. (2008). Edebiyat Kuramları, Tanım-Tenkit-Tahlil. İstanbul: Salkımsöğüt. 
Dil, Nihilizm ve Televizyon Yusuf Devran, Ömer Faruk Özcan

Küçükalkan, G. (2017). Anlamın Yapısökümü: Haberi Derrida'dan Okumak. (Yayımlanmamış doktora tezi). Erzurum: Atatürk Üniversitesi SBE.

Küçükalp, K. (2005). “Politik Nihilizm: Nietzscheci Bir Tartışma”, Bursa: Aktüel Yayınları.

Özkan, S. (2004). Nietzsche. İstanbul: Ötüken.

Robert S. Pritchard, M.A., APR, Fellow PRSA and Vincent F. Filak, Ph.D. Confronting Media Nihilism: How Transparency Builds Meaning During Crises, Public Relations Journal Vol. 4, No. 1, Winter 2010 